\title{
Natural Mineral Waters Enhance the Intestinal Health and Stimulate Anti-inflammatory Immune Response in Functional Cell Model of a Non-cancerogenic Human Gut
}

\author{
Martin Trapecar \\ Department of Biochemistry and Nutrition, University of Maribor \\ Faculty of Medicine, Slomskov trg 15, 2000 Maribor, Slovenia \\ Ales Goropevsek \\ Department of Biochemistry and Nutrition, University of Maribor \\ Faculty of Medicine, Slomskov trg 15, 2000 Maribor, Slovenia
}

$\&$

University Clinical Center Maribor, Ljubljanska ulica 5, 2000 Maribor, Slovenia

Lea Zbontar Zver

Research and Development Department, Radenska d.d.

Boraceva 37, 9502 Radenci, Slovenija

Avrelija Cencic (Corresponding author)

Department of Biochemistry and Nutrition, University of Maribor

Faculty of Medicine, Slomskov trg 15, 2000 Maribor, Slovenia

$\&$

Department of Microbiology, Biochemistry, Molecular Biology and Biotechnology

University of Maribor, Faculty of Agriculture and Life Sciences

Pivola 10, 2311 Hoce, Slovenia

Tel: 386-2320-9028Ｅ-mail: avrelija.cencic@uni-mb.si

Received: January 6, 2012

Accepted: January 19, $2012 \quad$ Published: May 1, 2012

doi:10.5539/jfr.v1n2p217

URL: http://dx.doi.org/10.5539/jfr.v1n2p217

\begin{abstract}
Background Although mineral waters have been used extensively in human nutrition and have widely recognized health related properties; the availability of data on the mechanisms of their actions is limited.

Methods and results We have therefore analyzed their ability to increase trans-epithelial resistance of small intestinal epithelia and cell renewal, the bioaccessibilityas well as evaluated their immunomodulatingpotentialin a 3D functional cell model of the gut. Results have showed that the mineral content is highly accessible to the human body. Moreover, carbonated natural mineral water increases the trans-epithelial resistance and epithelial proliferation. In the same time they enhance the anti-inflammatory response by inhibiting activation of TNF- $\alpha$ and stimulating the TGF- $\beta$ cytokine in healthy epithelia as well as in macrophages.

Conclusions We can conclude that by this action the mineral waters have the potential to increase the integrity of the small intestinal wall and its immune status. In addition to providing scientific grounds for a health-beneficial use of natural mineral water, this manuscript provides a novel methodology for the assessment of food derived bioactives in the human gut.
\end{abstract}


Keywords: Bioaccessibility, TER, Mineral water, 3D cell model, Human gut

\section{Introduction}

Consumption of packaged water increases year after yeardue to growing awareness of pollution and its impact on the quality of drinking water as well as higher consumer preferences for a healthy diet. Natural mineral water is by definition water that originates in an underground water source which is highly protected against pollution and contains naturally dissolved minerals and gasses. Mineral substances in natural mineral water are in an already dissolved form and can be directly absorbed into the human body via the gut.

Studies have shown that calcium and magnesium in natural mineral water are absorbed to a greater extent than those in other foods, even in comparison with milk (Ekmekcioglu, 2000; Marktl, 2009).

It has been shown previously, in a study of 300 post-mastectomy breast cancer patients and 150 patients after gastric resection for cancer, that a course intake of mineral water improves immune status.In both groups an intake of mineral water significantly raised the levels of T- and B-lymphocytes and their functional activity, and reduced blood levels of IgG and CIC providing immunological enhancement of tumor antigens (Vladimirov et al., 2004).

Concerning immunomodulating properties of natural mineral water, it was shown that some mineral waters have the ability to enhance the lympho-proliferative response to mitogens.

IL-4 and IFN-gamma production also increased in stimulated culture supernatants. Conversely, natural mineral water containing cell medium induced a decrease in IL-4 production by normal peripheral blood lymphocytes. Furthermore, the water amended the clinical features as well as the immunological Th2 profile of atopic dermatitis (Portales et al., 2001).

Although natural mineral water has been consumed for centuries and has many observed positive effects on human physiology (Nocco, 2008; Perez-Granados et al., 2010), there have been, to our knowledge, no major mechanistic studies done to prove or to explain previously described effects on the human organism.

Therefore, in this work we determine the validity of natural mineral water consumption by assessing bioaccessibility of different minerals $(\mathrm{Ca}, \mathrm{Na}, \mathrm{Mg}, \mathrm{K}$, microelements) from natural mineral waters with or without $\mathrm{CO}_{2}$, their potential to increase trans-epithelial resistance (TER) and cell proliferation, as well as the potential of natural mineral waters to activate the cytokine expression in healthy small intestinal tissue and in human monocytes.

Variousfavourable properties of different health promoting substances can be assessed In vitro by severalbiological tests, particularlyby using cell culture systems where direct effects of substances on intestinal and other cells can be monitored. While rapid growth in the field of genomics and proteomics with technological innovations in recent years provides new data, In vitro models are still essential tools in biological mechanistic and functional studies (Cencic \& Langerholc, 2010; Botic et al., 2007; Nissen et al., 2009).

Unfortunately, so far mostly tumorigenic and transformed cell lines have been widely used for mechanistic studies of the gastro-intestinal tract, despite their phenotype very distinguished from that of the normal gut epithelia.

In addition, these cell lines are mostly cultivated as monolayers on plastic surfaces in experimental models, where the establishment of functional, epithelial character is not defined (Cencic et al., 2010)

For these purposes, we developed a novel 3D human intestinal cell model consisting of untransformed human small intestinal epithelial cell line (H4 cl. 1) and human monocytes/macrophages cell line (TLT) in a system that closely mimics the small intestinal environment.

\section{Materials and Methods}

\subsection{Cells}

Thefollowing cell lines were used: H4-1 (non-transformed human foetal small intestinal cells) and TLT (non-transformed human monocyte/ macrophages). H4-1 and TLT were derived from healthytissues and are available from BioNutriTech Ltd. (Lunel, France).

Cells were generallymaintained in Dulbecco's modified Eagle's medium (DMEM) supplemented with 10\% fetal calf serum, L-glutamine $2 \mathrm{mmol} / \mathrm{l}$, penicillin (100 U/ml, Sigma) and streptomycin $(1 \mathrm{mg} / \mathrm{ml})$ at $37{ }^{\circ} \mathrm{C}$ in $5 \% \mathrm{CO}_{2}$ atmosphere in tissue culture flasks. 


\subsection{Natural mineral water and cell media}

To assay the biological effects of natural mineral water on different cell lines we incubated the cells during experimentation in cell culturemedia prepared with individual mineral water with or without $\mathrm{CO}_{2}$ or distilled water as a control. Prior to each experiment we prepared fresh DMEM supplemented with $10 \%$ foetal calf serum, L-glutamine $2 \mathrm{mmol} / \mathrm{l}$, penicillin (100 U/ml, Sigma) and streptomycin $(1 \mathrm{mg} / \mathrm{ml})$ by adding natural mineral water Radenska Classic (carbonated) or mineral water RadenskaNaturelle (uncarbonated) or distilled water,as a control, according to the producer's manual. In order to avoid influence of difference in $\mathrm{pH}$ we have adjusted the $\mathrm{pH}$ of all prepared media with natural mineral waters and distilled water to the same $\mathrm{pH}$ of 6,4 by using $1 \mathrm{M} \mathrm{HCl}$. The mineral water was donated from Radenskad.d. (Radenci, Slovenia). Their physical and chemical parameters relevant to this study are given in Table 1.

\subsection{Trans-epithelial resistance (TER)}

H4-1 cells were seeded on 12 well plates with microporous inserts (Milipore, USA) in a initial concentration of $1 \times 10^{5}$ cells per well and incubated at $37{ }^{\circ} \mathrm{C}$ in atmosphere of $5 \% \mathrm{CO}_{2}$. As soon as a confluent layer was formed we have measured the TER with Milicell ERS-2 (Milipore, USA) in each well daily till the $7^{\text {th }}$ day when TER has reached in average a constant resistance of $667 \mathrm{Ohm}$ as a sign for complete polarization and differentiation. At that point we have discarded the apical and basal supernatants and applied in each apical compartment $0,5 \mathrm{ml}$ of media prepared with mineral waters and the control. In the basal compartments we have pipetted 1,5 $\mathrm{ml}$ of regular DMEM media. TER was measured right after application, after 6 hours and 24 hours.

After 24 hours of incubation of the cells with the mineral waters and the control we have collected the basal supernatants of each well for further incubation with TLT macrophages and analysis of ion concentration.

\subsection{Bioaccessibility}

We have determined the bioaccessibility of magnesium $\left(\mathrm{Mg}^{2+}\right)$, calcium $\left(\mathrm{Ca}^{2+}\right)$, sodium $\left(\mathrm{Na}^{+}\right)$, potassium $\left(\mathrm{K}^{+}\right)$, chlorine $\left(\mathrm{Cl}^{-}\right)$and carbon dioxide $\left(\mathrm{CO}_{2}\right)$ by measuring.

the concentration of investigated ions in the collectedbasalsupernatants after a 24 hour incubation of the cells with mineral waters and the control with the Cobas c111 system (Roche, France). We expressed the bioaccessibility of single ionsas a percentage increase in concentration, compared to the control.

\subsection{Cell proliferation assay}

To perform cell proliferation assays, H4-1 cells were separately seeded in 96 well plates at a concentration of 10 viable cells per well. DMEM prepared with natural mineral waters and distilled water were added and incubated for 7 days at $37{ }^{\circ} \mathrm{C}$ in atmosphere of $5 \% \mathrm{CO}_{2}$. After incubation we stainedthecells with crystal-violet and counted the single formed colonies.

\subsection{Immunomodulating activity}

In order to determine the immunomodulating properties of natural mineral water we have cultivated TLT cells in 12 well plates at $37{ }^{\circ} \mathrm{C}$ in an atmosphere of $5 \% \mathrm{CO}_{2}$, until a confluent layer was formed. Later the supernatants have been exchanged with basal supernatants of the $\mathrm{H} 4$ 3D model. After 24 hours of incubation the expressionof TNF- $\alpha$, IL-10 and TGF- $\beta$ in TLT supernatants and H4 basal supernatants has been determined by ELISA. The ELISA kits for TNF- $\alpha$, IL-10 and TGF- $\beta$ were purchased from Invitrogen (UK). The increase or decrease of cytokines of mineral water treated cells is expressed as a percentage increase or decrease, compared to the control (cells incubated with DMEM prepared with distilled water).

\subsection{Statistical analysis}

Analysis of variance followed by unpaired Student's t-test were used to determine statistical differences between multiple groups; $p$-values $<0.05$ were considered statistically significant. All findings are expressed by the mean ratios $(\%, \pm \mathrm{SD})$ of results in treated wells as compared to those in control wells, of three individual experiments.

\section{Results}

\subsection{TER}

After initial application of carbonated, uncarbonated and control water on the H4-1 3D cell model a general decrease in trans-epithelial resistance was observed which started to increase in the course of the next 24 hours (Figure 1). The highest final TER was measured on cells incubated with carbonated mineral water (average TER of $737 \mathrm{Ohm}$ ) and the lowest on cells incubated with uncarbonated mineral water (average TER of $680 \mathrm{Ohm}$ ). Cells incubated with the control have shown a TER of 711 Ohms as shown in Figure 1. 


\subsection{Bioaccessibilityof minerals from natural mineral waters}

Bioaccessibility of the minerals dissolved in the mineral waters with or without $\mathrm{CO}_{2}$ in the novel human gut functional model was determined as described in Materials and Methods. The results clearly showed thatthe concentration of $\mathrm{Mg}^{2+}$ in the basal side of the H4-1 model incubated with carbonated mineral water increased by $100 \%$ compared to the control (DMEM prepared with distilled water only). Atthe same time we observed a high absorbance of $\mathrm{Ca}^{2+}$ via the small intestinal cell layer. The concentration of $\mathrm{Ca}^{2+}$ in the basal compartment of the H4-1 model incubated with carbonated mineral water has increased by $228.25 \%$ as compared to the control (DMEM prepared with distilled water only) (Figure 2).

The incubation of cells with uncarbonated mineral water resulted in a smaller increase in the concentration of $\mathrm{Mg}^{2+}$ and $\mathrm{Ca}^{2+}$ in the basal compartment of the functional cell model, as compared to carbonated mineral water. The concentration of $\mathrm{Mg}^{2+}$ has increased for $24 \%$ and that of $\mathrm{Ca}^{2+}$ for $109.71 \%$ (Figure 2).

The same pattern was observed in absorption of monovalent ions dissolvedin the tested mineral waters: a $7.83 \%$ increase of $\mathrm{Na}^{+}$, a $12.09 \%$ increase of $\mathrm{K}^{+}$and a $4.03 \%$ increase of $\mathrm{Cl}^{-}$in the basal compartments of the cells incubated with carbonated mineral water (Figure 2).

A similar trend was observed in H4-1 cellsincubatedwith uncarbonated mineral water. Compared to the control, the concentrations of $\mathrm{Na}^{+}, \mathrm{K}^{+}$and $\mathrm{Cl}^{-}$increased for $3.26 \%, 6.19 \%$ and $2.77 \%$, respectively.

The concentration of $\mathrm{CO}_{2}$ roseby $41 \%$ in the basal compartments of the functional cell model when the cells werecultured in DMEMwith carbonated mineral water and by $16 \%$ when the cells were incubated in DMEM with uncarbonated mineral water, as shown in Figure 2.

\subsection{Proliferative activity of natural mineral waters}

Incubation of intestinal cells with carbonated and uncarbonated mineral water (Figure 3) resulted in an increase in the number of colonies formed by cells of normal gut epithelia (H4-1) compared to the control. Carbonated mineral water (average of 80.8 colonies) showed a stronger proliferative effectthan uncarbonated mineral water( 73.3 colonies) whereas cells incubated with the control have formed in average 61,8 colonies.

\subsection{Immunomodulatingproperties of natural mineral waters}

By measuring the concentration of cytokines TNF- $\alpha$, IL-10 and TGF- $\beta$ in the supernatnats of TLT cells and basal supernatants of H4-1 cells a 5\% down regulation of TNF- $\alpha$ and IL-10 was observed in supernatants of H4-1 cells incubated in DMEMwithcarbonated and uncarbonated mineral water,compared to that in the control (Figure 4). Atthe same time, an up regulation of $5 \%$ was taking place for TGF- $\beta$ forcellsincubated in DMEM with uncarboanted water and 27\% for cells incubated in DMEM with carbonated mineral water.

During incubation of TLT macrophages with basal supernatants of H4-1 cells treated with mineral waters, a general down regulation of all cytokines could be observed when compared to the control (Figure 5).

\section{Discussion}

Despite many previously observed positive effects of natural mineral waters on human physiology (Nocco, 2008; Perez-Granados et al., 2010), there has been no evidence on potential mechanisms behind those effects.

In our novel human gut functional model we showed that minerals dissolvedincarbonated natural mineral waters are absorbed through the small intestinal epitheliumtoa much higher extent as compared to non-gaseous mineral waters (Figure 2) and that the minerals are highly available.

These findings are not surprising, as previously described by Missner et al. (Missner et al., 2008), $\mathrm{CO}_{2}$ increases the permeability of cellular membranes, resulting in a higher mineral intake.

In the same time carbonated mineral water is positively enhancing the trans-epithelial resistance of H4-1 cells (Figure 1). Intestinal epithelial cells are closely packed and form tight-junctions in order to regulate intestinal absorption and migration. TER is the parameter describing how well the cells are interlocked, differentiated and polarized (Langerholc et al., 2011). By enhancing TER, carbonated mineral water shows the potential to beneficially influence the integrity of the intestinal wall.

Regarding self-renewal, the intestine is one of the most proliferative organs of the human body. Frequent cellular turnover is necessary for its normal functioning therefore increased proliferation and renewal seems a promising attribute of carbonated mineral water.

The data obtained in testing the immunomodulatingproperties of natural mineral waters, especially of the mineral water with $\mathrm{CO}_{2}$ indicated that natural mineral water has the ability to down regulate proinflammatorycytokine expression by small intestinal epithelial cells and underlying monocytes/macropages (Figure 4). The water has 
significantly up-regulated the production of TGF- $\beta$ in H4-1 cells and at the same time suppressed its activation in TLT macrophages (Figure 4). It was reported before that TGF- $\beta$ appears to block the activation of lymphocytes and monocyte derived phagocytes (Leterrioand Roberts, 1998).

\section{Conclusions}

Modern day lifestyle, defined by a decrease in physical activity and an increase in unhealthy nutritional habits, gives rise to augmented incidence of intestinal inflammations, intestinal dysfunction and colon cancer (Labianca et al., 2010).

Our study suggests that regular intake of carbonated natural mineral water bears the potential to ease symptoms associated with above mentioned conditions. The findings demonstrate that natural mineral waters present a valuable source of macro- and microelements which are highly bioaccessible to the human organism, beneficially influence cellular turnover and contribute to the positive regulation of gut immunological responses. A clinical trial is currently running to support our claims.

In this manner, our report emphasizes also the importance of mechanistic studies to elucidate clinical evidence as well as the importance of utilizing appropriate models which mimic the In vivo environment as close as possible. In models that represent a healthy gut environment, untransformed and non-carcinogenic cell lines should be applied, such as in the model employed in this study.

\section{References}

Botić, T., Klingberg, T. D., Weingartl, H., \& Cencic, A. (2007). A novel eukaryotic cell culture model to study antiviral activity of potential probiotic bacteria. International Journal of Food Microbiology, 115, 227-34. http://dx.doi.org/10.1016/j.ijfoodmicro.2006.10.044

Cencic, A., \& Langerholc, T. (2010). Functional cell models of the gut and their applications in food microbiology - a review. International Journal of Food Microbiology, 141, 4-14. http://dx.doi.org/10.1016/j.ijfoodmicro.2010.03.026

Ekmekcioglu, C. (2000). Intestinal bioavailability of minerals and trace elements from milk and beverages in humans. Nahrung, 390-7. http://dx.doi.org/10.1002/1521-3803(20001201)44:6<390::AID-FOOD390>3.0.CO;2-Y

Kolesnikov, O. L., Selianina, G. A., Dolgushin, I. I., \& Kolesnikova, A. A.(2002). The question of mechanisms of the immunotropic effect of mineral drinking waters. Voprosy Kurortologii, Fizioterapiii Lechbnoi Fizicheskoi Kultury, 3, 15-7.

Labianca, R., Beretta, G. D., Kildani, B., et al. (2010).Colon cancer. Critical Reviews in Oncology/Hemathology, 74, 106-133. http://dx.doi.org/10.1016/j.critrevonc.2010.01.010

Langerholc, T., Maragkoudakis, P. A., Wollgast, J., Gradisnik, L., \& Cencic, A. (2011). Novel and established intestinal cell line models - An indispensable tool in food science and nutrition. Trends in Food Science \& Technology, 22, 11-20. http://dx.doi.org/10.1016/j.tifs.2011.03.010

Letterio, J. J., \& Roberts, A. B. (1998). Regulation of immune responses by TGF- $\beta$. Annual Review of Immunology, 16, 137-161. http://dx.doi.org/10.1146/annurev.immunol.16.1.137

Marktl, W. (2009). Gesundheitliche Bedeutung Natürlicher Mineralwässer. Wiener KlinischeWochenschrift, 121, 544-550. http://dx.doi.org/10.1007/s00508-009-1244-1

Missner, A., Kügler, P., Saparov, S. M., Sommer, K., Mathai, J. C., Zeidel, M. L., \& Pohl, P. (2008). Carbon dioxide transport through membranes. Journal of Biological Chemistry, 283(37), 25340-25347. http://dx.doi.org/10.1074/jbc.M800096200

Nissen, L., Chingwaru, W., Sgorbati, B., Biavati, B., \& Cencic, A. (2009). Gut health promoting activity of new putative probiotic/protective Lactobacillus spp. strains: a functional study in the small intestinal cell model. International Journal of Food Microbiology, 135, 288-94. http://dx.doi.org/10.1016/j.ijfoodmicro.2009.08.027

Nocco, P. B. (2008). Mineral water as a cure. Veroffentlichungen der Schweizerischen Gesellschaft fur Geschichte der Pharmazie, 29, 13-402.

Pérez-Granados, A. M., Navas-Carretero, S., Schoppen, S., \& Pilar-Vaquero, M. (2010). Reduction in cardiovascular risk by sodium-bicarbonated mineral water in moderately hypercholesterolemic young adults. The Journal of Nutritional Biochemistry, 21, 948-953. http://dx.doi.org/10.1016/j.jnutbio.2009.07.010

Polushina, N. D., Vladimirov, V. I., \& Frolkov, V. K. (2002). Effect of drinking mineral water on hormonal regulation of glucose homeostasis after mastectomy for breast cancer. Voprosy Kurortologii, Fizioterapiii Lechbnoi Fizicheskoi Kultury, 6, 19-21. 
Portalès, P., Ariès, M. F., Licu, D., Pinton, J., Hernandez-Pion, C., Gall, Y., Dupuy, P., Charveron, M., \& Clot, J. (2001). Immunomodulation induced by Avène spring water on Th1- and Th2-dependent cytokine production in healthy subjects and atopic dermatitis patients. Skin Pharmacology and Applied Skin Physiology, 14, 234-42. http://dx.doi.org/10.1159/000056352

Radenskad.d. (2011). Internal quality report. Radenskad.d..

Vladimirov, V. I., Laktionova, A. I., \& Polushina, N. D. (2004). Drinking mineral waters in rehabilitation of cancer patients. Voprosy Kurortologii, Fizioterapiii Lechbnoi Fizicheskoi Kultury, 4, 16-9.

Table 1. Physical and chemical parameters of the mineral waters

\begin{tabular}{ccc}
\hline Parameter & $\left.\begin{array}{c}\text { Radenska Classic } \\
(\text { Mineral water withCO }\end{array}\right)$ & $\begin{array}{c}\text { Radenska Naturelle } \\
\left(\text { Mineral water without } \mathrm{CO}_{2}\right)\end{array}$ \\
\hline $\mathrm{pH}$ & 6,4 & 7,3 \\
$\mathrm{Mg}^{2+}$ & $92 \mathrm{mg} / 1$ & $20 \mathrm{mg} / 1$ \\
$\mathrm{Ca}^{2^{+}}$ & $200 \mathrm{mg} / 1$ & $47 \mathrm{mg} / 1$ \\
$\mathrm{Na}^{+}$ & $440 \mathrm{mg} / 1$ & $7,4 \mathrm{mg} / 1$ \\
$\mathrm{~K}^{+}$ & $80 \mathrm{mg} / 1$ & $0,8 \mathrm{mg} / 1$ \\
$\mathrm{Cl}^{-}$ & $44 \mathrm{mg} / 1$ & $3,4 \mathrm{mg} / 1$ \\
\hline
\end{tabular}

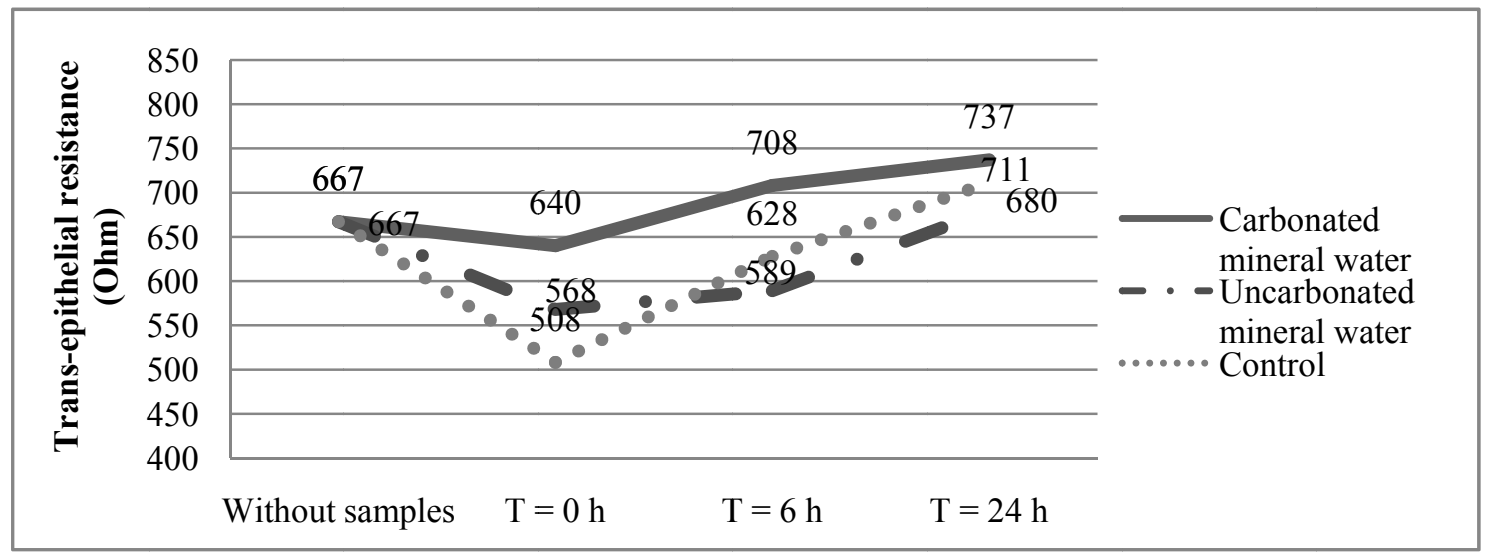

Figure 1. The initial TER of H4-1cells before samples were applied was $667 \mathrm{Ohm}$. After application of mineral waters a general decrease in TER has been observed. After 24 hours the TER of cells incubated with carbonated water was $737 \mathrm{Ohm}$, the one of cells incubated with uncarbonated water 680 TER and the control $711 \mathrm{Ohm}$. The values represent an average of 3 individual experiments

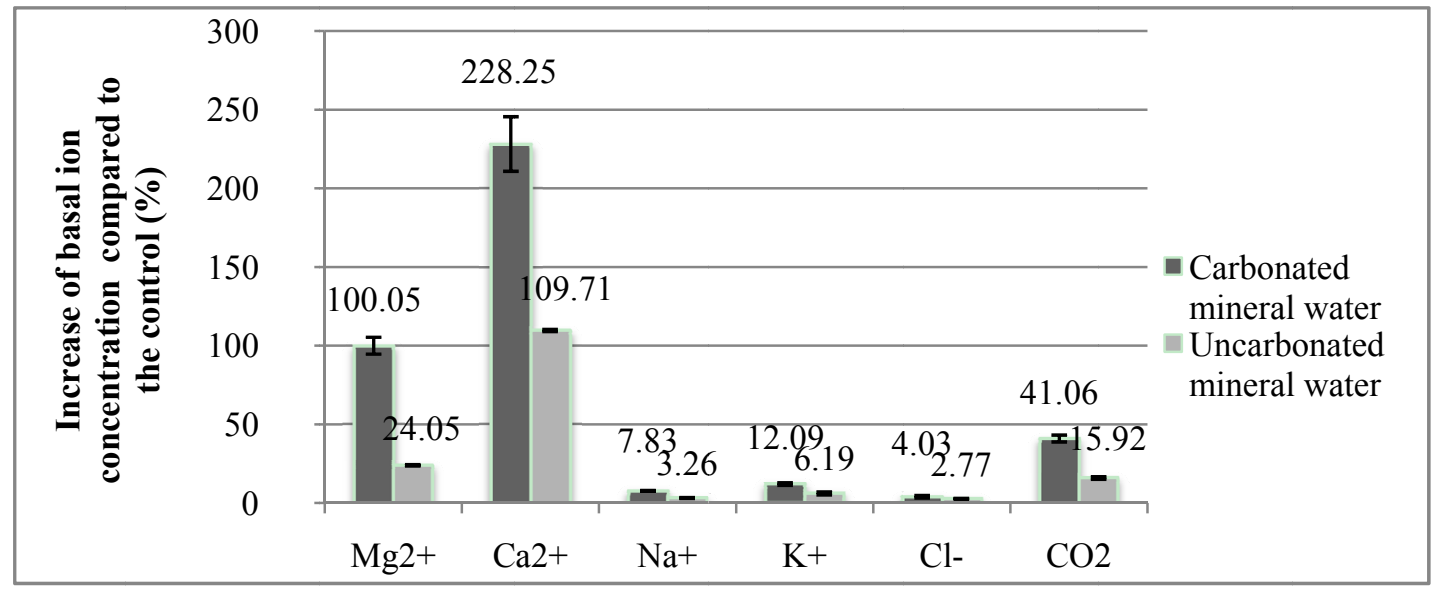

Figure 2. Increase of basal ion concentration. The increase of each ion is expressed as mean $\pm \mathrm{SD}(\mathrm{n}=3)$ of the average concentration as compared to the control 


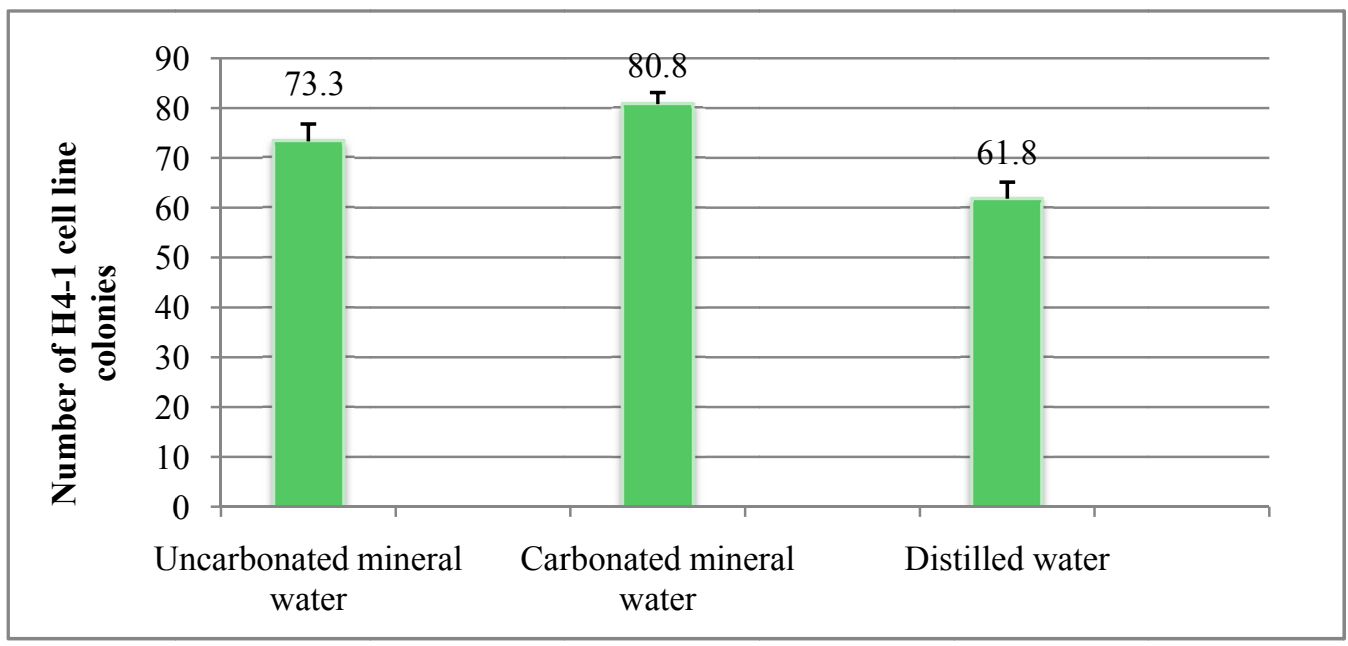

Figure 3. Number of colonies formed by H4-1 (untransformed intestinal epithelial cells) after incubation in DMEM with carbonated, uncarbonated and distilled water for 7 days at $37^{\circ} \mathrm{C}$. The effect on the proliferation of each water is expressed as mean $\pm \mathrm{SD}(\mathrm{n}=3)$ of the number of colonies formed as compared to the control

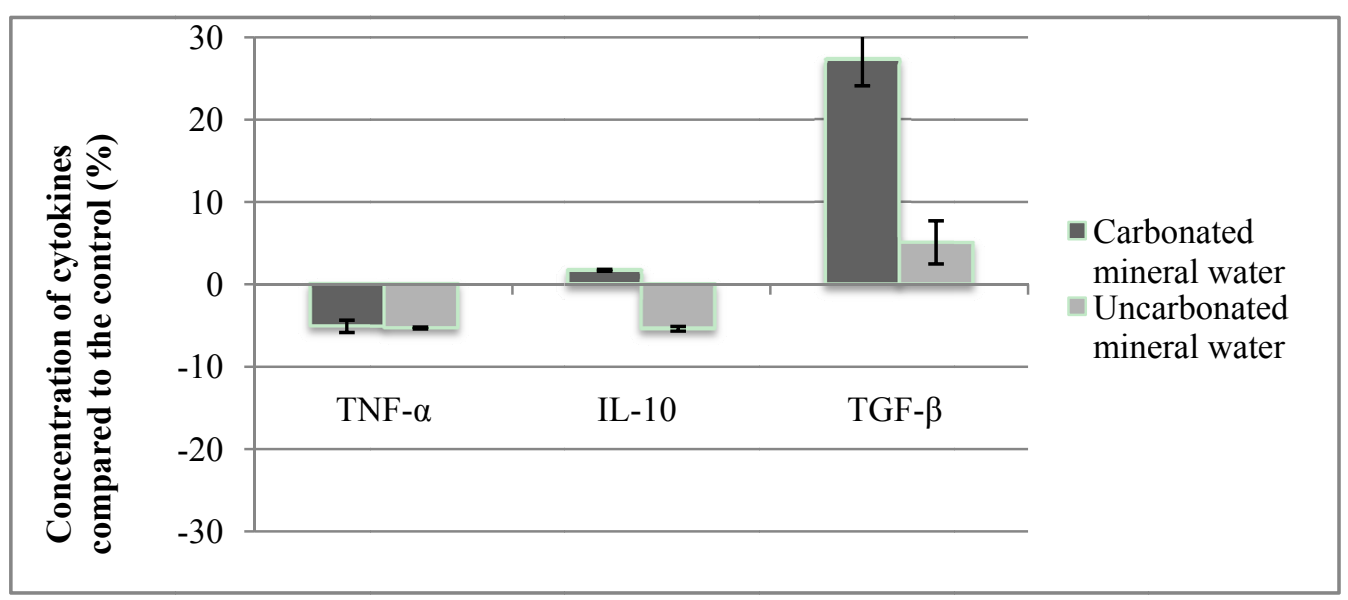

Figure 4. The difference of cytokine activation in H4-1 cells after incubation in DMEM with natural mineral waters and the control for 24 hours at $37^{\circ} \mathrm{C}$ expressed as percentage compared to the control (cells incubated in $\mathrm{DMEM}$ with distilled water). The percentage of difference is expressed as mean $\pm \mathrm{SD}(\mathrm{n}=3)$

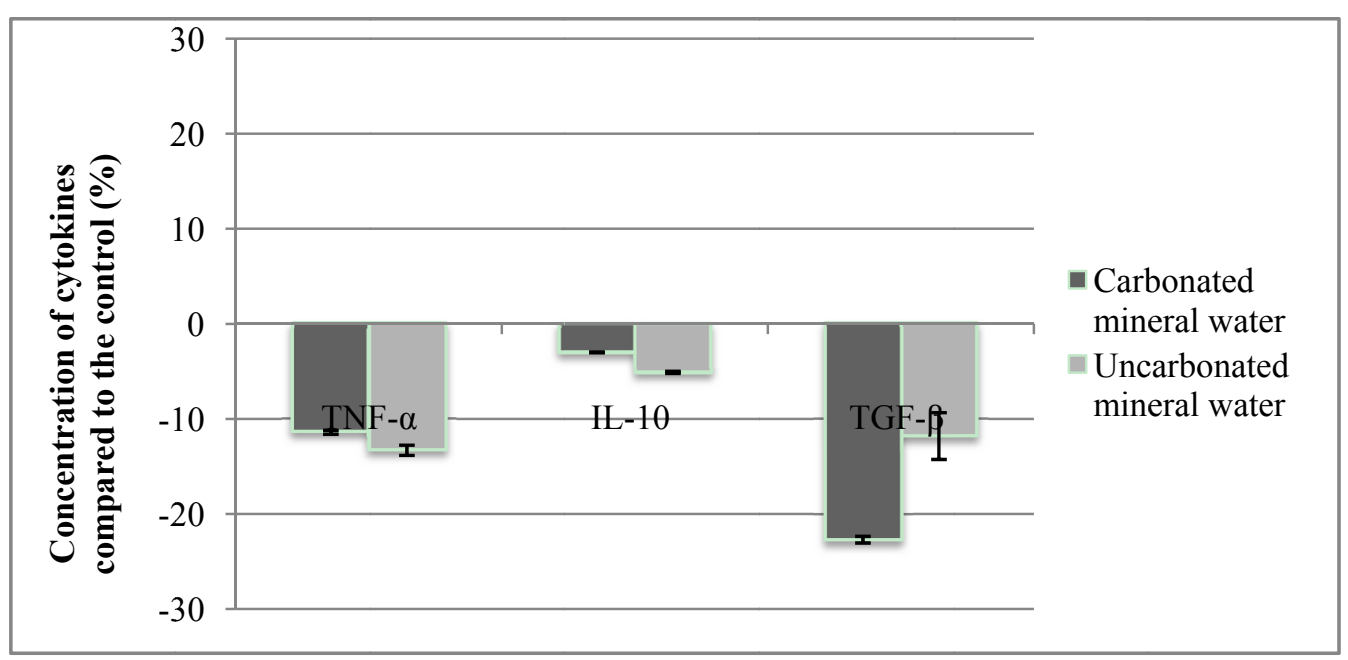

Figure 5. The difference of cytokine activation in TLT macrophage cells after incubation in DMEM with natural mineral waters and the control for 24 hours at $37^{\circ} \mathrm{C}$ expressed as percentage compared to the control (cells incubated in DMEM with distilled water). The percentage of difference is expressed as mean $\pm \operatorname{SD}(n=3)$ 